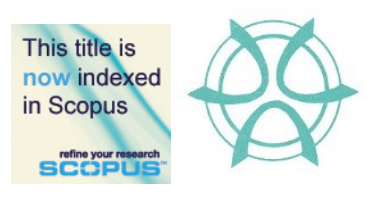

PLANNING MALAYSIA:

Journal of the Malaysian Institute of Planners

VOLUME 19 ISSUE 1 (2021), Page 41 - 52

\title{
LOCATION HOUSING AFFORDABILITY INDEX: ANALYSING THE RELATIONSHIPS
}

\author{
Mohd Azren Hassan', Yusfida Ayu Abdullah², Dasimah Omar', Muhammad \\ Hakim Danial ${ }^{4}$ \\ ${ }^{1,2,3,4}$ Centre of Studies for Town and Regional Planning, \\ Faculty of Architecture, Planning and Surveying \\ UNIVERSITI TEKNOLOGI MARA, MALAYSIA
}

\begin{abstract}
Previous studies claimed that Malaysia is inclined towards a severely unaffordable housing price. Despite such crucial studies, the topics do not provide sufficient empirical evidence to establish a relationship between housing prices, housing and transportation expenditure in Malaysia. Therefore, this study examines the role of these variables in determining the Location Housing Affordability Index. The research had therefore identified measurement items that contribute to Location Housing Affordability Index. The primary data was obtained from urban areas in the Klang Valley using questionnaires, where a total of 363 respondents were selected using the Simple Random Sampling technique. The Partial Least Squares (PLS) method was adopted in analysing the collected data to determine the relationship. The outcome demonstrated the relationship between housing price, housing and transportation expenditure, indicating the significance of the Location Housing Affordability Index and can be a reference for housing policymakers.
\end{abstract}

Keywords: Location Housing Affordability Index; Housing Price; Housing Expenditure, Transportation Expenditure

\footnotetext{
${ }^{1}$ Lecturer at Universiti Teknologi MARA email: azren446@uitm.edu.my
} 
Mohd Azren Hassan, Yusfida Ayu Abdullah, Dasimah Omar, Muhammad Hakim Danial

Location Housing Affordability Index: Analysing the Relationships

\section{INTRODUCTION}

Housing acts as an important determinant of a family's quality of life. Therefore, owning a home is the dream of every individual. Yip et al. (2019) also assert that housing is a fundamental economic and social need for everyone to have a right to be provided. It should be as affordable and appropriate as their basic needs. Globally, house ownership ability is crucial for the housing market. Homeownership is not just to own a place to live but exceeds the fundamental necessity. For some people, it is their single largest investment within their lifetime, which will lead to increased personal well-being that creates economic stability. Ismail et al. (2020) suggested that housing affordability stress provides a meaningful measure of various household well-being elements and can be concluded that housing stress does indeed have a constructive impact on household well-being. Finding affordable, secure and appropriate housing is typically one of the biggest issues of Malaysian households today. Majid (2017) have concluded that the housing prices in Malaysia depend on various factors like population, demand and supply, location, physical characteristic, accessibility, developer of the housing complex, the cost of construction materials and the median income. Housing affordability ensures the houses provided are affordable for all groups; the high-income, middle-income or low-income groups.

\section{RESEARCH BACKGROUND}

The affordability problem concerning the housing market is one of the most controversial issues in most developed and developing countries (Sohaimi et al., 2017). Housing affordability is one's financial ability to pay the costs involved in owning a home. According to Hulchanski's (1995) report on housing affordability in major cities, factors affecting buying a home can be divided into macro and micro factors. Macro factors are housing prices, location, financial loans, financial loans interest rates, monthly payments, and money or cash advance process. At the same time, micro factors are monthly income, occupation, age, consumption patterns, total dependency, monthly money surplus and much more (DiPasquale and Wheaton, 1996). Subsequently, the economic factor of a household is the focal problem for housing affordability.

Households at different stages of life have distinct mobility frequencies as economic and demographic characteristics change, resulting in different housing needs and priorities regarding housing choices. When getting older, socio-economic features (gender, age, ethnicity), life-course events, financial status, and the community environment (such as neighbourhood features and access to services) all influence one's housing location choice (Han et al., 2019; Osman et al., 2017). Location is a major factor in housing and transportation expenditure, particularly the distance between residential neighbourhoods and employment centres. 
PLANNING MALAYSIA

Journal of the Malaysia Institute of Planners (2021)

Relation to the role of location and affordability are strongly reflective in the housing market. Likewise, Saleh et al. (2016) found a correlation between housing price and location due to workplace factor and the limited choice to reallocate affordable housing. Meanwhile, Saberi et al. (2017) further elaborated that housing affordability must include the geographic location of the house and the accessibility to transport infrastructure. Transportation expenditure is the amount of spending on transportation for each household to conduct their daily activities, such as working, recreational, and groceries (Giuliano, 1998). Meanwhile, Greenlee et al. (2016) added that transportation expenditure would be a better factor in measuring affordability and overall housing cost in terms of locality, making the trade-offs easier for movers to discern and capitalize upon. Furthermore, the measurement of housing affordability is considered flawed without considering the transportation expenses. For that matter, transportation expenditure should not be excluded from any affordable housing scheme.

Several studies agree that transportation expenditure should be included as part of housing affordability calculation (Hassan et al., 2018; Hartell, 2017; Litman, 2014; Isalou et al., 2014; Sabri et al., 2013). A journey to a specific place determines the distance that would significantly impact transportation expenditures. Transportation expenditure is the amount of spending on transportation for a households' mobility to do their daily activities such as working, recreational activities, and do their groceries. The amount of spending depends on their house's location, whether near the employment and commercial centres. Location affordability, therefore, is the aptitude of access to transport obtained goods and services at any given time; hence location affordability explains the pattern of residential mobility (Greenlee et al., 2016).

There is a consensus among researchers suggesting that if by combining housing and transportation expenditure, it accounts for less than $45 \%$ of overall household expenditures. The housing, then, can be considered affordable. (Lipman, 2014; Mattingly \& Morrissey, 2014; Center for Transit-Oriented Development and Center for Neighborhood Technology, 2006). Using this measurement will have many implications, such as identifying a suitable location for developing truly affordable housing. Simultaneously, the result could be taken as a piece of advice for future homeowners on choosing a home. The concept of location affordability adopts the approach in assuming that any consideration of housing affordability will augment by considering the transport expenditures incurred because of a location choice (Litman, 2014; Hartell, 2017).

Hence, Location Housing Affordability Index, a measurement adapted by Hassan (2018), has identified three main variables household income, housing and transportation expenses, to measure housing affordability.

This research was developed along the approach mentioned above to evaluate the relationship among the three variables and determine the level at which such a relationship could accomplish the measurement of location housing 
Mohd Azren Hassan, Yusfida Ayu Abdullah, Dasimah Omar, Muhammad Hakim Danial

Location Housing Affordability Index: Analysing the Relationships

affordability. The general objective of this research is to assess the relationship between household income, housing, transportation expenditure that would then indicate location housing affordability. The objectives are as follows.

1. To ascertain the relationship between housing price and location housing affordability.

2. To find out whether the housing expenditure has influenced location housing affordability.

3. To find out the extent to which transportation expenditure is involved in location housing affordability.

\section{Hypothesis Development}

Extensive reviews on location housing affordability suggested three independent variables: household income, housing expenditure, and transportation expenditure. Figure 1 below shows the conceptual framework for this study based on the literature reviews.

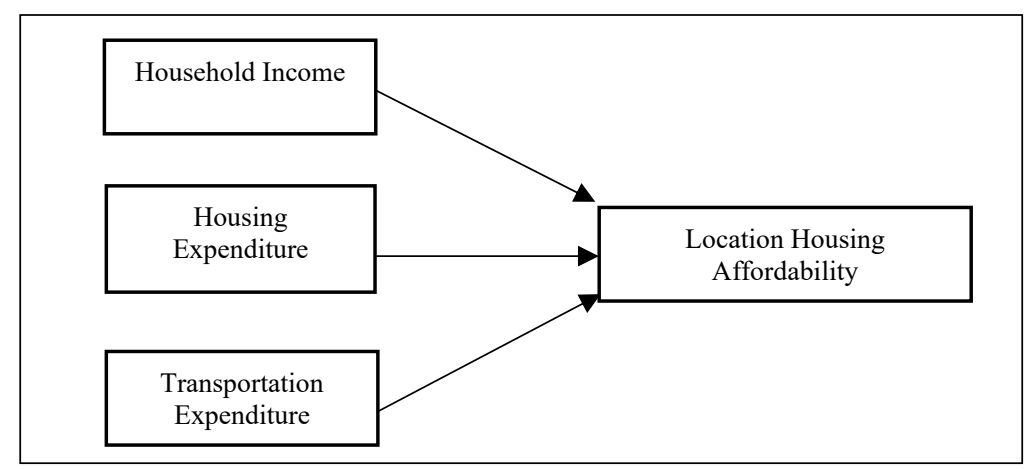

Figure 1: Conceptual Framework of Location Housing Affordability

Table 1 below shows the three (3) latent constructs and all the items applied to measure the independent variables. Concerning the latent constructed and measurement variables, the following hypotheses were thus developed:

H1: There is a positive relationship between household income and location housing affordability.

$\mathrm{H} 2$ : There is a positive relationship between housing expenditure and location housing affordability.

H3: There is a positive relationship between transportation expenditure and location housing affordability 
PLANNING MALAYSIA

Journal of the Malaysia Institute of Planners (2021)

Table 1: Latent Construct and Measure Items

\begin{tabular}{|c|c|c|}
\hline Latent Construct & Measure Items & Reference \\
\hline $\begin{array}{l}\text { Household } \\
\text { Income }\end{array}$ & $\begin{array}{l}\text { Age } \\
\text { Marital status } \\
\text { Homeowner } \\
\text { Respondent work experience } \\
\text { Spouse working } \\
\text { Spouse's salary } \\
\text { Respondent's salary }\end{array}$ & $\begin{array}{l}\text { Khazanah Research Institute, } \\
\text { (2015),); Chowdhury (2013; } \\
\text { Bujang et al., (2010); Mallach } \\
\text { (2009); Stone (2006); Quigley } \\
\text { and Raphael (2004); Swartz et } \\
\text { al. (2002) and Whitehead (1991) }\end{array}$ \\
\hline $\begin{array}{l}\text { Housing } \\
\text { Expenditure }\end{array}$ & $\begin{array}{l}\text { Current residence } \\
\text { Housing price } \\
\text { Monthly mortgage / rent } \\
\text { Utility bills }\end{array}$ & $\begin{array}{l}\text { Khazanah Research Institute, } \\
\text { (2015); Mattingley \& Morrissey } \\
\text { (2014); Jewkes \& Delgadillo, } \\
2010 \text { and Mahamud and Hussein } \\
(2002)\end{array}$ \\
\hline $\begin{array}{l}\text { Transportation } \\
\text { Expenditure }\end{array}$ & $\begin{array}{l}\text { Number of vehicles } \\
\text { Vehicle payment monthly } \\
\text { Vehicle expenses annually } \\
\text { Expenses for toll and parking monthly } \\
\text { Repair and maintenance monthly } \\
\text { Distance to workplace } \\
\text { Usage of public transit } \\
\text { Expenses on public transit monthly } \\
\text { Fuel usage monthly }\end{array}$ & $\begin{array}{l}\text { Greenle et al. (2016); } \\
\text { Mattingley \& Morrissey (2014); } \\
\text { Litman (2014) and Center for } \\
\text { Transit-Oriented Development } \\
\text { and Center for Neighborhood } \\
\text { Technology (2006) }\end{array}$ \\
\hline
\end{tabular}

\section{METHODOLOGY}

For the research, primary information has been the source of information to determine the research hypothesis. A quantitative method was applied to answer some key questions about the factors influencing location housing affordability. Personal administered using questionnaires survey was instrumental in investigating household income, housing and transportation expenditure. Based on these three aspects, the questionnaire survey was divided into three (3) parts to systematically categorised the research. To ensure the researcher, together with the research team, could collect the completed response within a time limit, a simple random sampling was used to select the respondents. The number of respondents sampling was based on Krejcie \& Morgan (1970). The total sample size was 363 respondents. This research had chosen the population from three urban areas in Klang Valley; Kerinchi, Subang Bestari and Putra Height.

The Partial Less Square (PLS) was chosen to analyze the data with the help of SMART PLS 2.0. PLS is a combination of factor analysis and regression or path analysis. It is also to facilitate the model relationship between both latent and observed variables. For this research, PLS-SEM was also used to determine the relationship between variables in location housing affordability and household income, housing expenditure, and transportation expenditure. 
Mohd Azren Hassan, Yusfida Ayu Abdullah, Dasimah Omar, Muhammad Hakim Danial

Location Housing Affordability Index: Analysing the Relationships

\section{RESULT AND DISCUSSION \\ Internal Consistency Reliability}

The Internal Consistency Reliability test was also utilised due to its ability to measure consistent results when the same entities were measured under different conditions. The importance of conducting the reliability test is to determine the prerequisite validity of the collected data. The action is to prevent invalidity of collected data due to its inconsistent and reliable measurement (Field, 2013). To measure the reliability test is by finding the Cronbach's alpha. Cronbach's alpha indicates the degree of internal consistency and function of the item number in the scale and the inter-correlations with each item.

When measuring items that are highly related data, the alpha value is high. The low measurement of alpha will indicate that the items do not correlate with each other. Meanwhile, some guidelines can be applied to medium-stakes tests, where the reliability of 0.70 is sometimes considered minimally acceptable, 0.80 is decent, 0.90 is quite good, and anything above 0.90 is excellent. Simultaneously, others also mentioned that the internal consistency reliability measured between 0.80 and 0.70 is highly acceptable. For this research, the reliability coefficient for each latent construct ranged from 0.82 to 0.71 . Therefore, the three latent constructs were exceeding the minimum acceptable level of 0.70 , and this shows that there is adequate internal consistency reliability of the measure used for this research.

\section{Convergent Validity and Discriminant validity}

Convergent validity refers to the extent to which items truly represent the intended latent construct and share a high proportion of variance in common (Hair et al., 2006). This research estimates its convergent validity using factor loadings, average variance extracted (AVE), and composite reliability (CR). As Hair et al. (2017) suggested, the value for loadings is at least 0.5 , a composite reliability value of 0.7 and the value of AVE is at least 0.5 . The result shows all the item loading being above 0.5 and only one AVE value is above 0.5 , which is transportation expenditure (0.53). The other two constructs recorded less than 0.5 are household income $(0.48)$ and housing expenditure $(0.46)$. The composite reliability value for all constructs is above 0.7 . The construct for household income value is 0.86 , while housing expenditure is 0.77 and transportation expenditure is 0.91. Fornell and Larcker (1981) stated that if an AVE value is less than 0.5 , but the composite reliability is higher than 0.6 , the convergent validity of the construct is still acceptable. Therefore, the household income and housing expenditure constructed in this research were adequate. Hence, it can be established that all three constructs had agreeable convergent validity and can measure the research concepts. 
PLANNING MALAYSIA

Journal of the Malaysia Institute of Planners (2021)

Discriminant validity compares item loadings with item cross-loading and, at the same time, a comparison of the variance extracted from the constructed shared. The intended construct loading should be on the higher side than other constructs. Simultaneously, discriminant validity can also be tested by comparing correlations of the square root of an AVE construct with other constructs. The result shows the square root of AVEs (number in bold) is considerably higher than its correlations with other constructs. The household income construct value for the square root AVE is 0.69 , which is higher than the other constructs; housing expenditure is 0.63 and transportation expenditure is 0.49 . The housing expenditure construct value for the square root AVE is 0.68 , which is higher than the transportation expenditure construct (0.66). The transportation expenditure construct value for the square root AVE is 0.73 . Hence, the constructs have adequate discriminant validity and can be used to measure the research concept.

\section{Structural Model Specification}

A model's exploratory power is usually measured using R-square $\left(R^{2}\right)$. The $R^{2}$ is known as the coefficient of determination. This explains the quality of the measurement and the variance of the endogenous variable, which in this research is the dependent variable in the Location Housing Affordability Index. The measurement of $\mathrm{R}^{2}$ is by the proportion of the variant dependent variable that is explained by the independent variables. Hair et al. (2017) explained further that they need to have $10 \%$ for suitable explanatory power because it can show the strength of the relationship between the dependent variable and independent variable. The analysis revealed in Table 2 and Figure 2 below demonstrates that the structural modal's dependent variable has substantial significance with an $R^{2}$ at $89 \%$. Therefore, the dependent variable has a substantial and acceptable $R^{2}$ value.

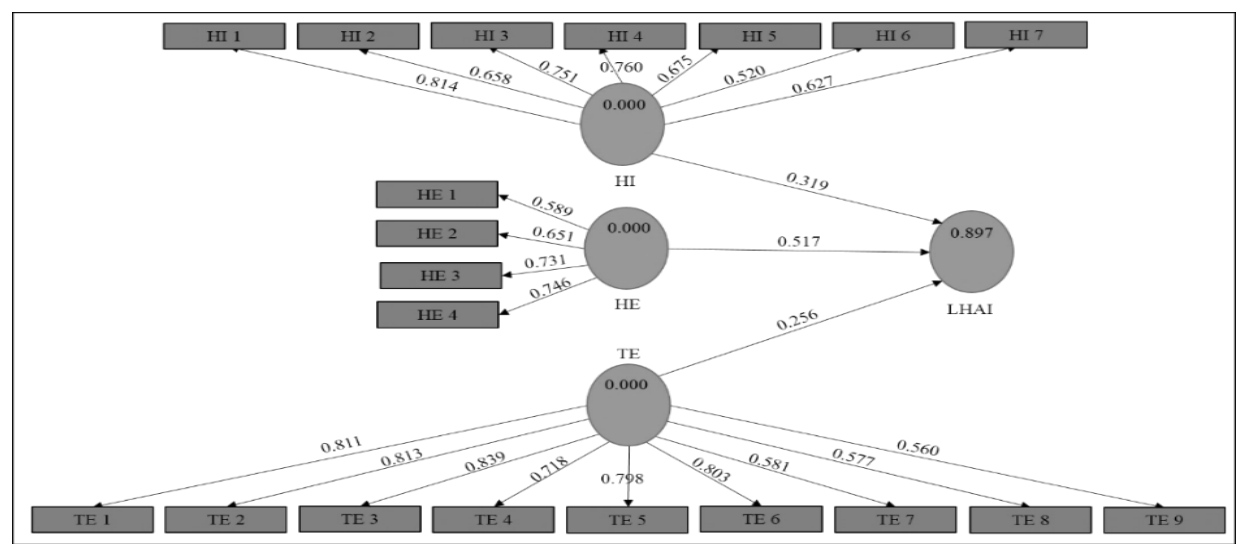

Figure 2: The Result of Path Analysis

Note: HI (Household Income); HE (Housing Expenditure); TE (Transportation Expenditure), LHAI (Location Housing Affordability Index). 
Mohd Azren Hassan, Yusfida Ayu Abdullah, Dasimah Omar, Muhammad Hakim Danial

Location Housing Affordability Index: Analysing the Relationships

Table 2: Structural Specification for Dependent Variable

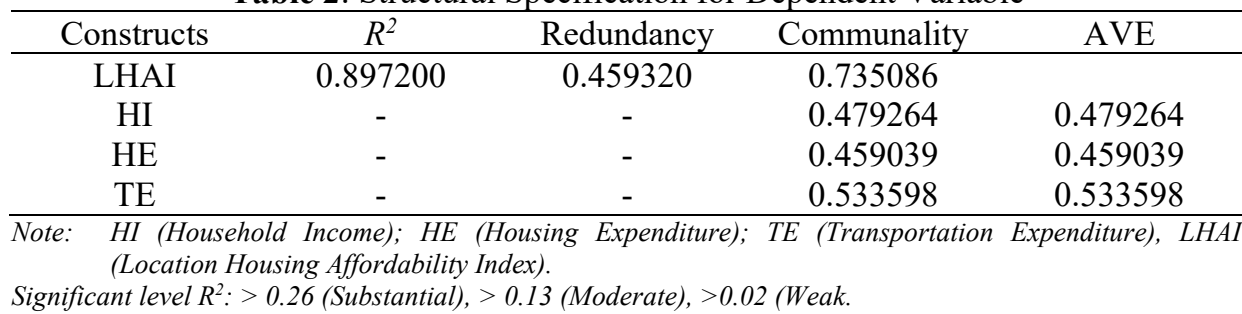

\section{Assessment of Effect Size ( $\left.f^{2}\right)$}

The effect size for levels of Location Housing Affordability is $85.4 \%$ for household income, $46.6 \%$ for housing expenditure and transportation expenditure is $21.4 \%$. Household income and housing expenditure have a large effect, and transportation expenditure has a moderate effect, as shown in Table 3 . This shows that all the constructs for this research have met the effect size specification of the structural model.

Table 3: Assessment of Effect Size on the Structural Model

\begin{tabular}{ccccc}
\hline \multirow{2}{*}{$\begin{array}{c}\text { Latent } \\
\text { Construct }\end{array}$} & $\begin{array}{c}\text { Included } \\
\text { Value }\end{array}$ & $\begin{array}{c}\text { Excluded } \\
\text { Value }\end{array}$ & \multirow{2}{*}{$f^{2}$} & \multirow{2}{*}{ Sign } \\
\cline { 2 - 3 }$R^{2}$ Full Model & $R^{2}$ Excluded & & $* * *$ \\
HI & 0.897 & 0.809 & 0.854 & $* * *$ \\
TE & 0.897 & 0.849 & 0.466 & $* *$ \\
\hline Note: HI Household Income) $\cdot H E$ (Housing Expenditure) $\cdot T E$ (Transportation Expenditure) &
\end{tabular}

Note: HI (Household Income); HE (Housing Expenditure); TE (Transportation Expenditure)

$f^{2}$ is assessed as: $>0.35$ (large) $* * *,>0.15$ (moderate) $* *$ and $>0.02$ (small)*

\section{Assessment of Predictive Relevance}

Assessment of Predictive Relevance $\left(Q^{2}\right.$ and $\left.q^{2}\right)$ is also known as the blindfolding procedure. This procedure was used to test the predictive relevance of the research approach. This procedure is considered important because by using PLS, prediction purposes require a measure of predictive capability. This procedure represents a synthesis of cross-validation and function fitting with a perspective that the prediction of observable or potential observables is much higher relevance than the estimation of what are often artificial construct parameters. This ensures the cross-validation test fits soft modelling like a hand in glove (Ramayah, 2014).

To validate this test, observing the $Q^{2}$ value was undertaken, where $Q^{2}>$ 0 indicates that the model has predictive relevance for a specific latent construct; however, $Q^{2}<0$ indicates a lack of predictive relevance (Hair et al., 2017). For this research, all the latent constructs show that their values are $>0$. Therefore, the structural model is a good predictive relevance $Q^{2}$. 
Additionally, to assess the $Q^{2}$ values, the $q^{2}$ value is calculated to estimate the effect size approach. This is to make sure the relatives' latent variables affect either small, medium or large. In order to assess the value of the relative measures, predictive relevance is divided into three values. The values are $0.02,0.15$ and 0.35, as stated in Hair et al. (2017), represent an exogenous construct (independent variable) that has a small, moderate and large predictive relevance for a specific endogenous construct (dependent variable). The result is shown in Table 4 below clearly shows that all three latent constructs have a large predictive relevance of $q^{2}>0.35$.

Table 4: The Relatives Impact of Predictive Relevance on Observed

\begin{tabular}{|c|c|c|c|c|c|}
\hline $\begin{array}{c}\text { Latent } \\
\text { Construct }\end{array}$ & $\begin{array}{c}Q^{2} \text { included } \\
\text { (a) }\end{array}$ & $\begin{array}{l}Q^{2} \\
\text { (b) }\end{array}$ & $Q^{2}$ excluded & $q^{2}$ & Sign. \\
\hline $\mathrm{HI}$ & 0.523317 & 0.449782 & 0.073535 & 0.94356627 & $* * *$ \\
\hline $\mathrm{HE}$ & 0.523317 & 0.47215 & 0.051167 & 0.99049054 & $* * *$ \\
\hline TE & 0.523317 & 0.439413 & 0.083904 & 0.92181387 & $* * *$ \\
\hline
\end{tabular}

Note: HI (Household Income); HE (Housing Expenditure); TE (Transportation Expenditure)

$q^{2}$ is assessed as: $>0.35$ (large) $^{* * *},>0.15$ (moderate) ${ }^{* *}$ and $>0.02$ (small)*

\section{Hypothesis Testing}

This research interpretation of the hypothesis testing was based on the one-tailed $t$-statistics value of $p<0.01$ with the degree of freedom of 433 . For this research, three hypotheses were tested. The hypothesis is to make sure there is a relationship between the independent variables with the non-independent variable.

Therefore, the three hypotheses are H1: Household Income -> Location Housing Affordability Index, H2: Housing Expenditure -> Location Housing Affordability Index and H3: Transportation Expenditure -> Location Housing Affordability Index. The result in Table 5 shows that all three hypotheses supported the relationship. The relationship between household incomes has an at-value of 11.96. Housing Expenditure has the highest t-value among the three hypotheses, which is 16.19 and transportation expenditure has a t-value of 9.18, which is the lowest t-value. Nevertheless, all three hypotheses are supported at the p-value of 0.01 .

Table 5: Hypothesis Testing

\begin{tabular}{cccccc}
\hline Hypothesis & Relationship & Std. Beta & Std. Error & t-value & Decision. \\
\hline H1 & HI -> LHAI & 0.32 & 0.03 & $11.96^{* * *}$ & Supported \\
H2 & HE -> LHAI & 0.52 & 0.03 & $16.19 * * *$ & Supported \\
H3 & TE -> LHAI & 0.26 & 0.03 & $9.18^{* * *}$ & Supported \\
\hline Note: & HI (Household Income); HE (Housing Expenditure); TE (Transportation Expenditure), LHAI \\
(Location Housing Affordability Index). & & & \\
If**) significant at $\mathrm{p}<0.01$ & & & \\
If t-value is greater than 2.58 (significant at $\mathrm{p}<0.01$ ) & & &
\end{tabular}


Mohd Azren Hassan, Yusfida Ayu Abdullah, Dasimah Omar, Muhammad Hakim Danial

Location Housing Affordability Index: Analysing the Relationships

Therefore, the result demonstrated a positive relationship between Location Housing Affordability Index with the three independent variables. The high value of $R 2(0.89)$ shows that all the variables are significant for Location Housing Affordability Index as a measuring tool. This was earlier expected as many new measurements to determine housing affordability includes all three variables as main variables to identify housing affordability (Isalou, 2014; Litman 2014, 2011; Mattingly and Morrissey, 2014; Center for Transit-Oriented Development and Center for Neighborhood Technology. 2006; Gabriel et al., 2005).

Transportation expenditure inclusivity in housing affordability calculation gives more significance regarding location affordability; furthermore, it also mirrors the actual cost of living (Saberi et al., 2017). The correlative result and its relationship indicate that a household does not necessarily avoid homeownership stress by moving to a suburban city. The highest coefficient parameter is the housing expenditure with 0.52 , which indicates that suburban households are then exposed to higher transportation expenditure. These findings, therefore, concur with the result of research done by Vidyattma (2013). From all the above discussions, it can be concluded that the Location Housing Affordability Index could be used as a measuring tool to measure housing affordability, including transportation expenditure, especially since transportation expenditure has stronger empirical evidence towards housing affordability.

As Greenle et al. (2016) stated, transportation expenditure will be a better factor in measuring affordability and overall housing expenditure depending on locality. Therefore, making the trade-offs is easier for movers to discern and capitalize. Including transportation expenditure in determining housing affordability could change the development of policies that affect affordable housing that is heavily reliant on its location, transport and at the same time, the employment centre.

\section{CONCLUSION}

This research provided evidence to the growing body of knowledge concerning the relationship between housing price, housing and transportation expenditure, and location housing affordability. Results from this research lend support to the key theoretical proposals. In particular, the current research has successfully responded to all the research objectives despite some of its limitations. Additionally, the contribution to identifying and empirically proving that location does matter in housing affordability will be beneficial to future policymakers to build more affordable housing near an employment centre that could impact the vitality of households. Hence, it is noteworthy to highlight the significant function of the Location Housing Affordability Index as a measurement tool in the planning and development of future housing schemes. 


\section{REFERENCES}

Center for Transit-Oriented Development and Center for Neighborhood Technology. (2006). The Affordability Index: A New Tool for Measuring the True Affordability of a Housing Choice. Urban Market Initiative.

DiPasquale, D. and Wheaton, W. C. (1996). Urban Economics and Real Estate Markets (Vol. 23). Prentice-Hall Englewood Cliffs, NJ.

Field, A. (2013). Discovering Statistics Using IBM SPSS Statistics. Sage Publication.

Fornell, C. and Larcker, D. F. (1981). Evaluating Structural Equation Models with Unobservable Variables and Measurement Error. Journal of Marketing Research.

Gabriel, M., Jacob, K., Arthurson, K., Burke, \& T., Yates, J., (2005). Conceptualising and Measuring the Housing Affordability Problem. Australia Housing and Urban Research Institute

Giuliano, G. (1998). Urban Travel Patterns. John Wiley \& Sons Ltd.

Greenlee, A.J. \& Wilson, B.K. (2016): Where Does Location Affordability Drive Residential Mobility? An Analysis of Origin and Destination Communities. Housing Policy Debate, DOI: 10.1080/10511482.2016.1163611

Hair Jr, J. F., Sarstedt, M., Ringle, C. M., \& Gudergan, S. P. (2017). Advanced Issues in Partial Least Squares Structural Equation Modelling. SAGE Publications.

Han, H., Jung, Y. M., \& Xiong, X. (2019). Housing and Location Choice. In The Ageing of Australian Ethnic Minorities, (pp. 49-60). Palgrave Pivot, Singapore.

Hartell, A. M. (2017). Evaluating the Concept of Location Affordability: Recent Data on the Relationship between Transportation, Housing, and Urban Form. Housing Policy Debate, 27(3), 356-371.

Hassan, M. A., Hamdan, H., Abdullah, J., \& Abdullah, Y. A. (2018). Housing and Transportation Expenditure: An Assessment of Location Housing Affordability. Journal of the Malaysia Institute of Planners, 16(2), 99-108.

Hassan, M. A., Hamdan, H., Abdullah, J., \& Abdullah, Y. A. (2017a). Locatıon Housing Affordability as an Indicator for Quality of Life in Malaysia. EnvironmentBehaviour Proceedings Journal, 2(6), 247-253.

Hassan, M. A., Hamdan, H., \& Abdullah, J. (2017b). A Conceptual Overview of Sociospatial Pattern for Housing Affordability of Urban Area in Malaysia. Journal of Applied Environment and Biological Science, 7(5S), 41-44.

Hulchanski, D. J. (1995). The Concept of Housing Affordability: Six Contemporary Uses of the Housing Expenditure to Income Ratio. Housing Studies, 10(4), 21.

Isalou, A. A., Litman, T., \& Shahmoradi, B. (2014). Testing the Housing and Transportation Affordability Index in a Developing World Context: A Sustainability Comparison of Central and Suburban Districts in Qom, Iran. Transport Policy, 33, 33-39. https://doi.org/10.1016/j.tranpol.2014.02.006

Ismail, A., Bujang, A. A., Jaafar, M. N., Jiram, W. A., \& Wijayaningtyas, M. (2020). Housing Affrodability Stress: A Literature Survey and Some Evidence from Malaysia. Jurnal Kemanusiaan, 18(1).

Krejcie, R. V, \& Morgan, D. W. (1970). Determining Sample Size for Research Activities Robert. Educational and Psychological Measurement, 38(1), 607-610. https://doi.org/10.1177/001316447003000308

Litman, T. (2014). Transportation Affordability. Victoria Transport Policy Institute. 
Mohd Azren Hassan, Yusfida Ayu Abdullah, Dasimah Omar, Muhammad Hakim Danial

Location Housing Affordability Index: Analysing the Relationships

Litman T. (2011). Affordable - Accessible Housing Inn Dynamic City. Why and How to increase Affordable Housing Development in Accessible Location; Victoria T. P Policy Institutes,

Mattingly, K., \& Morrissey, J. (2014). Housing and Transport Expenditure: Socio-spatial Indicators of Affordability in Auckland. Cities, 38, 69-83.

Ramayah, T. (2014) SmartPLS 2.0, School of Management, Universiti Sains Malaysia, Penang.

Majid, R. A., Said, R. \& Chong, J., T., S. (2017). Assessment of Bubbles in the Malaysian Housing Market. Journal of the Malaysia Institute of Planners, 16(2), 99-108.

Osman, M. M., Rabe, N. S., Abdullah, M. F., Rosli, N. F., \& Zainudin, F. E. (2017). Housing affordability in the state of Melaka. Planning Malaysia, 15(1). 225-260.

Saberi, M., Wu, H., Amoh-gyimah, R., \& Smith, J. (2017). Measuring Housing and Transportation Affordability: A case study of. Journal of Transport Geography, 65(May), 134-146. https://doi.org/10.1016/j.jtrangeo.2017.10.007

Sabri, S., Ludin, A.N.M \& Johar, F. (2013). Assessment of Neighbourhood Affordability Based on Housing and Transportation Cost in Kuala Lumpur, Malaysia. Journal of the Malaysia Institute of Planners, II(1), 75-100.

Saleh, A. F. A., Hwa, T. K., \& Majid, R. (2016). Housing Mismatch Model in Suburban Areas. Procedia - Social and Behavioural Sciences, 234, 442-451. https://doi.org/10.1016/j.sbspro.2016.10.262

Sohaimi, N. S., Abdullah, A., Shuid, S., \& Sarkawi, A. A. (2017). Young Professional Housing Affordability Through Housing Preferences in Kuala Lumpur and a Review on the Means-end Chain Model. Journal of the Malaysia Institute of Planners, 15(1), 369-376.

Vidyattama, Y., Tanton, R., \& Nepal, B. (2013). The Effect of Transport Costs on Housing - Related Financial Stress in Australia. Urban Studies, 50 (July), 1779 1795. https://doi.org/10.1177/0042098012468342

Yip, C.Y., Au, Y. H. \& Senadik, A. (2019) The Nexus between Housing Glut, Economic Growth, Housing Affordability and Housing Price in Malaysia. Journal of the Malaysia Institute of Planners, 17(1), 267-279.

Received: $4^{\text {th }}$ January 2021. Accepted: $22^{\text {nd }}$ April 2021 